\title{
"Readiness of the education manager to provide the organizational development of institutions (based on the sociological research)"
}

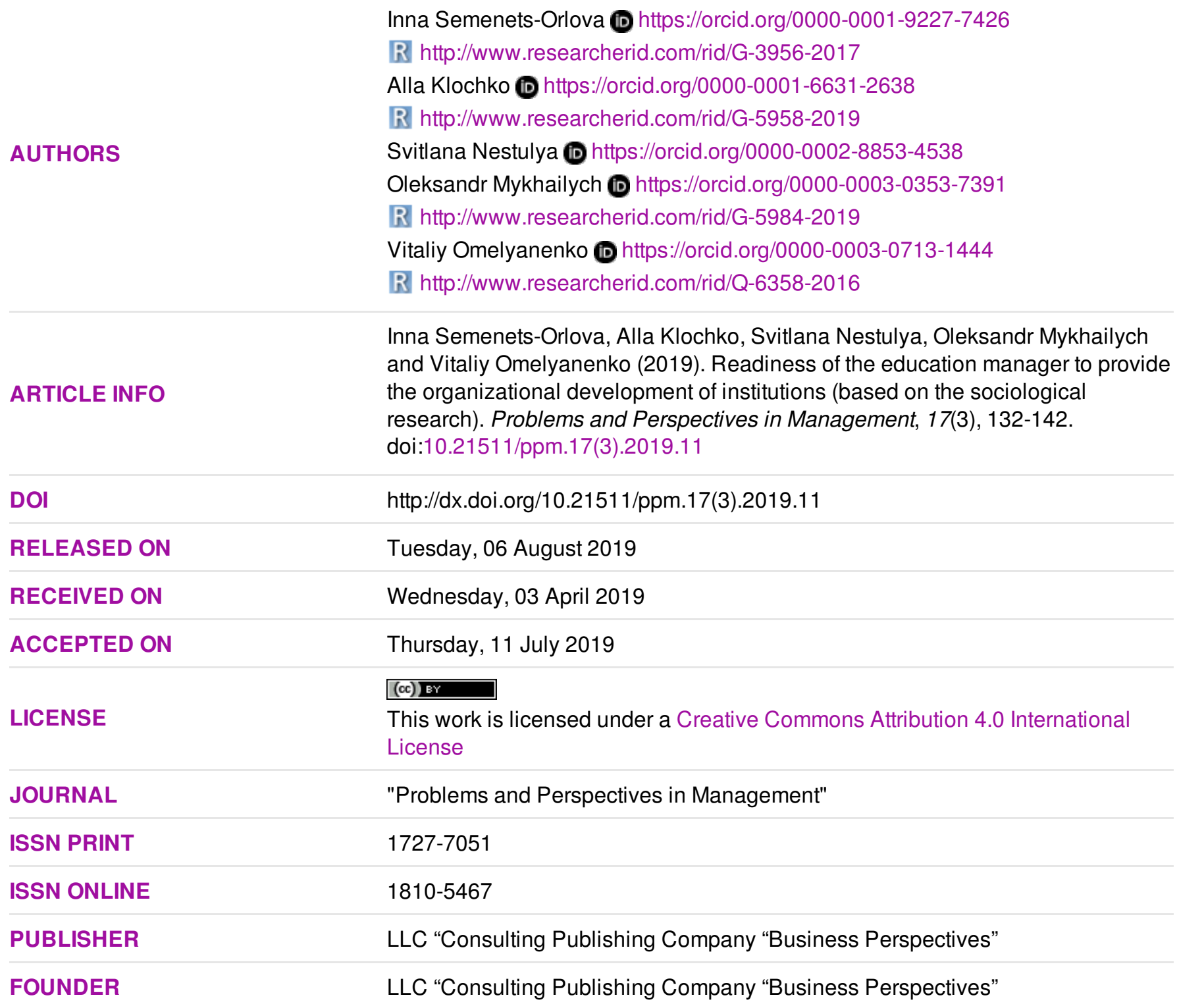

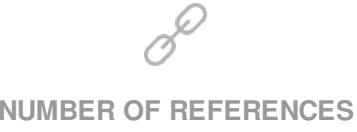

34
NUMBER OF FIGURES

1
NUMBER OF TABLES

2

(C) The author(s) 2021. This publication is an open access article. 


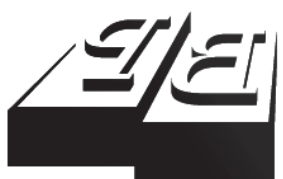

BUSINESS PERSPECTIVES

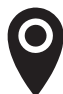

LLC "CPC "Business Perspectives" Hryhorii Skovoroda lane, 10, Sumy, 40022, Ukraine

www.businessperspectives.org

Received on: $3^{\text {rd }}$ of April, 2019 Accepted on: $11^{\text {th }}$ of July, 2019

(C) Inna Semenets-Orlova, Alla Klochko, Svitlana Nestulya, Oleksandr Mykhailych, Vitaliy Omelyanenko, 2019

Inna Semenets-Orlova, Doctor of Public Administration, Associate Professor, Department of Sociology and Political Science, National Aviation University, Ukraine.

Alla Klochko, Ph.D. in Pedagogy, Associate Professor, Bilotserkivskiy Institute of Continuous Education of State Higher Educational Institution "University of Educational Management", Ukraine.

Svitlana Nestulya, Ph.D. in History, Associate Professor, Department of Personnel Management and Labor Economics, Higher Educational Establishment of Ukoopspilka "Poltava University of Economics and Trade”, Ukraine.

Oleksandr Mykhailych, Ph.D. in Sociology, Associate Professor, Department of Sociology and Political Science, National Aviation University, Ukraine.

Vitaliy Omelyanenko, Ph.D. in Economics, Associate Professor, Department of Business Economics and Administration, Sumy State Pedagogical University named after A. S. Makarenko, Ukraine.

\section{(ㄷ)(ㄱ)}

This is an Open Access article, distributed under the terms of the Creative Commons Attribution 4.0 International license, which permits unrestricted re-use, distribution, and reproduction in any medium, provided the original work is properly cited.
Inna Semenets-Orlova (Ukraine), Alla Klochko (Ukraine), Svitlana Nestulya (Ukraine), Oleksandr Mykhailych (Ukraine), Vitaliy Omelyanenko (Ukraine)

\section{READINESS OF THE EDUCATION MANAGER TO PROVIDE THE ORGANIZATIONAL DEVELOPMENT OF INSTITUTIONS (BASED ON THE SOCIOLOGICAL RESEARCH)}

\begin{abstract}
The article contains the analysis of scientific approaches to understanding of organizational development in the field of educational institutions management as a complex of successive educational changes. Scientific researches on the change of education managers' behavior in the course of changes are presented.

Types of education managers attitude to changes and their quantitative expression were determined and revealed based on the data of an empirical research. Almost half of the surveyed education managers are represented by such types as "traditionalist" and "realist", which indicates the insufficient orientation of education managers in introducing innovative changes in educational institutions. This indicates a low level of education managers' readiness to provide the organizational development of educational institutions.

The results obtained can be used by the government in developing and implementing the programs for the professional development of education managers. The authors offer the most practical tools for implementing the concept of organizational development. It is proposed to distinguish between special requirements for both professional and personal qualities of education managers.
\end{abstract}
Keywords
educational institutions, changes, readiness, style, leadership, professional development

\section{JEL Classification D04, D20, D23, I21}

\section{INTRODUCTION}

The theory of organizational development is the scientific and methodological basis for developing the institutional capacity, ensuring the activity effectiveness and disclosing the leadership potential of educational institutions in the conditions of modern social transformations. Confirming the defining role of organizational development for realization of an institutional mission and the objectives, the theorist Salmi (2009) noted that implementation of programs of organizational development allows turning productively the vision of an institution into specific objectives. However, it confers a special responsibility on education managers, after all, they have to initiate, project, coordinate the introduction of programs of organizational development.

In this sense, the models and management styles of the educational institutions become particularly important when providing the organizational development of the institutions according to requirements of their transformation into institutes of innovative type. "To survive 
and be successful, - Druker writes, - each organization has to turn into the agent of changes". For this purpose, he continues, "it is necessary to completely change the installations... Instead of considering changes as threat, it is necessary to use them as opportunities" (Druker, 2003, p. 297). According to him, only those organizations, which will be guided by the principle, will be able to become successful: "Innovations have to be systematic". The education manager capable of managing the innovations will be able to maintain the stable functioning of systems and their institutions.

Organizational development is a process of continuous changes. A task of the education manager is to train employees for changes. As Semenets-Orlova (2017) states, education managers provide an insufficient training of personnel for innovations, not properly consider the need to observe the compulsory procedures of educational changes introduction, neglect them or are not even familiar. Therefore, $25 \%$ of teachers felt full support from education managers. In $20 \%$ of teachers, the low level of leadership potential and inactive participation of education managers became an obstacle for introduction of changes. $48 \%$ of respondents see a problem in the low level of the equipment in the educational institutions. $36 \%$ indicated the level of personnel competence. The following empirical data are confirmed by low readiness of education managers to provide procedural correctness of process of changes: $27 \%$ of teachers understood the purposes of changes, $39 \%$ noted appropriate consultation at the beginning of process of changes, $18 \%$ - were acquainted with possible risks, which are connected with changes, and they analyzed them. In addition, as it appeared, for $20 \%$ - the content of the process of educational changes was completely relevant strategies of development of educational institution (Semenets-Orlova, 2017, pp. 65-67). In this paper, we will try to prove or disprove the view of the low level of readiness of education managers to provide organizational development of educational institutions based on the model of consistent small changes, which combined with one strategic goal.

\section{LITERATURE REVIEW}

According to modern Western theorists of educational changes, organizational development is the long-term program for improvement of processes of organizational changes and decision-making based on cooperation, in particular, means of effective management of organizational culture (Gummings \& Worley, 2009). The last are characterized by a special focus on the culture of formal working teams, by means of agents or catalysts of changes, with the use of theories and methods of applied sciences about behavior, including a research by action. Thus, understanding of teachers by communities headed by their leaders of basic organizational parameters, general processing of them, formulations and formations are premises for ensuring effective organizational development of educational institution.

Such approach to understanding of organizational development re-actualizes classical theories of management of changes, which will be methodologically valuable, and management of education- al institutions, in particular, K. Levin's approach about importance of a context in formation of individual actions, proceeding from the theory of the field and gestalt psychology (Burnes \& Cooke, 2012, p. 411). Levin's pupils - Koch and French - have further developed the scientific approach of the scientist. Their two main conclusions are as follows:

1. resistance to changes arises not from the certain person, but from organizational environment;

2. for achievement of desirable result of innovations in the organization, the changes of a force field should take place through encouragement of joint decision-making in the course of vigorous cogitative, research activity (democratic participation), but not imposing of change.

Levin's pupils in Harvard University performed various experiments and showed that the success of changes was directly proportional to the degree of participative activity of employees (Coch \& French, 1948, p. 522). 
Therefore, in order to change the behavior of workers in the course of changes, education managers need to change the approaches to management of changes (Semenets-Orlova, 2016, p. 63). The Ukrainian scientists emphasize the need to considerably reconstruct the higher education as a source of intellectual resources and to develop the culture of transfer of innovative technologies among higher education students (Omelyanenko, Semenets-Orlova, Khomeriki, Lyasota, \& Medviedieva, 2018, p. 462). In the conditions of progressive changes in the society, the importance of radical educational changes, the idea of contents and a role of future education manager as a manager with the developed socially important professional, leadership and personal skills, ready to changes and creative activities extend. Innovative models of management and organizational structures corresponding to them have to be used in the institutions aimed at the continuous development and innovations.

In contemporary accountability frameworks, educational managers are positioned as being essential to improving the school performance and driving the innovations.

Holloway et al. (2017) analyze the growing trend of distributed leadership among teachers who are put in charge of assuming the leadership roles while maintaining their (sometimes reduced) teaching duties. The researcher underlines the tendency of leadership democratization (Holloway et al., 2017). Talmor Farchi and Dorit Tubin as Israeli researchers found that on the pyramid of school needs, administrative practices are more essential for school effectiveness. Nevertheless, satisfying the administrative needs depends largely on the principal providing them with the necessary rules and resources (Farchi \& Tubin, 2018).

Rose Ngozi Amanchukwu as Nigerian researcher found that success is certain if the leadership styles, principles and methods are properly applied in school management. Because quality educational leadership tradition offers great chance to further refine educational leadership and management policies and practices by accepting and utilizing the basic principles and styles of educational leadership (Amanchukwu, Stanley, \& Ololube, 2015).
Masitah Shahrill as Brunei researcher felt that it there was a need to establish the relationship between educational leadership and educational management. His conclusion is that these two educational spheres are different in terms of context and style, but each field does carry almost the same responsibility (Shahrill, 2014).

Connolly, James, and Fertig (2017) review the essence of educational management. They underline that "educational management entails the responsibility for the proper functioning of a system in an educational institution in which others participate" (Connolly, James, \& Fertig, 2017). According to Michael Connolly, although educational leadership is ideally undertaken responsibly, in practice it does not necessarily bring about the responsibility for the functioning of the education system, in which influence is exercised. However, nowadays educational responsibility is an important notion and should play a more prominent role in an analysis of formation in educational institutions (Connolly, James, \& Fertig, 2017). So, educational management becomes more important. In this article, we will determine the correlation between the necessary skills of education managers for educational management and for educational leadership in introducing the organizational changes.

Valuable theories of leadership of Kuczmarski became the answer to a series of bankruptcies and financial frauds of externally safe companies and rapid growth of value of personnel for effective functioning of the organizations at the end of 19th - the beginning of the 20th century. Their authors focus attention on motivational value of basic values for disclosure of employees' potential. The development, attraction to realization of tasks of the organization was proclaimed as a main objective of the leader who should have relevant personal qualities and styles of behavior in order to achieve it. Valuable theories of leadership re-actualize traditional ideas of Levin of how the organization and group dynamics affect individual readiness and motivation of workers for changes and continuous self-improvement. Organizational values work only when they are shared by all the co-workers/community members (Senge, 2006).

In the mid-nineties, the model of transformational leadership offered by B. Bass was considerably 
expanded in order to increase a number of descriptors, which defined the behavior of the leader, and emotional maintenance of changes on each of stages of their introduction (Kotter, 2012; Kotter \& Cohen, 2012). Transformational leadership theories created the basis for formation of new type of leadership concept, which received the name "innovative" and aims at creation of the institutions capable of developing and constantly changing (Ronen, 2019). Ilana Ronen as Israeli researcher underlines that "Ways to respond to the (education change) challenge are based on: developing emotional awareness; encouraging self-reflective processes; and fostering transformative leadership" (Ronen, 2019).

The provisions of the theory of "the engine of the leadership" by Tichy about importance for effective introduction of changes of the developing leadership at all levels of the organization are also important for their formation (Tichy \& Cohen, 2002, pp. 11-12). For example, for distribution of "network" of leaders at all levels of organizational management and across the organization, the author of the concept "internal stimulation of leadership" Cashman (2008) claims that it is necessary to wake up internal leadership potential, which each person has.

Tony Bush as British researcher provides an overview of modern models of educational leadership. One of the most important of these models is instructional leadership as path with the continuous learning of the teacher and the students. Tony Bush had coined the term "educational leadership as crowded territory” (Bush, Bell, \& Middlewood, 2019).

The emotional intelligence is the main instrument of realization of leadership skills in the theory of emotional leadership of Goleman (Goleman, 2016), which is shown through personal (consciousness, self-checking) and social (social flexibility, management of the relations) skills and positive (resonant) on influence on followers' style of behavior (ideological, educational, social, democratic) (Hura, 2018). It is important for establishment of mutual trust and the relations of cooperation in the group of workers. The so-called concept "binding or "unifying" leadership (LipmanBlumen) is based on achievement of the balance between motives of the leader and the objectives of his followers (Leavitt \& Lipman-Blumen, 2001), which in the traditional scheme of Lewin is called "employee contract with the organization".

Proceeding from results of the analysis of efficiency of various approaches to organizational development in the Australian educational system, made by Mulford, the educational manager as responsible for organizational development is called to perform the following functions (Silins, Mulford, \& Zarins, 2002, p. 619):

1) search of the facts aimed at defining the initial state of the institution specificity of the current problems of its functioning, the analysis of feedback;

2) activities for creation of teams - determination of the skills necessary for solving the problems of strategic development of the institution, assessment of requirements for creation of temporary teams;

3) educational and training events aimed at improvement of skills, abilities and knowledge of employees, such as technical, and at improvement of their interpersonal or social competence;

4) improvement of organizational structure of an institution by change of tasks, technologies, development of internal and external communications, distribution of participants' practice of decision-making;

5) mediation, preventions and resolutions of conflicts as the actions based on knowledge of confrontational tactics, understanding of processes of emergence of the conflicts and methods of their resolution;

6) development of individual recommendations, which is done by the consultant or the trained members of the organization, working with a group, aimed at:

a) helping the employees to define the goals of vocational education;

b) showing what are the expectations of personnel from professional activity of the teacher; 
c) teaching new ways of behavior, which will allow the teachers to achieve the goals, to conduct a joint research of alternative ways of behavior of teachers;

7) planning of life and career of teachers, which allows to be focused on strengthening of orientation to a human factor, recognition of importance of quality of employees' labor that positively affects work motivation, and, therefore, the efficiency of the institution in general.

According to the logic of Blake and Mounton, organizational development should be begun with training of education managers in leadership skills, then development of their leadership abilities, followed by measures for improvement and development of teams, and after that passing to development of the intergroup relations (Gebert \& Rozenshty, 1981). Later stages include corporate planning, acquisition by workers of tactical skills of implementation of plans, and finally pierces out the phase of assessment of changes in organizational culture and definition of future areas of work. Stalnaker (2018) underlines that for the success of organizational transformations, the important role of group organizational actions and behavior of workers in the workplace are the matters.

We will try to find out based on an empirical research whether the education managers are ready to provide it, as is it possible to increase their readiness. Insufficiently researched is the scientific problem of determining the level of readiness of managers to provide the continuous organizational development of educational institutions. Not enough complex in the scientific literature was analyzed the problem of modern methods of improving the education managers' skills of educational changes management.

Accordingly, the aim of this paper is to analyze the readiness of the education manager to provide organizational development of the institution (based on the data of a sociological research).

\section{METHOD}

The research methods are a combination of scientific principles, general philosophical, general scientific, special methods and methodological approaches to substantiation of managerial processes concerning the progressive changes in education. The research observes the principles of objectivity, scientific pluralism, systemacity, consistency, integrity, complexity and specificity. The methodological basis of the paper is a systematic approach. The logical-semantic method was used in the study of the conceptual-categorical apparatus of educational changes management theory. The method of structural and functional analysis enabled to reveal the nature and peculiarities of the functioning of the educational institution management system.

The synergistic method was used for the systematic understanding of the essence of educational change and nature of readiness of the manager for educational changes management. The method of empirical information analysis, the results of sociological research were used to analyze the effectiveness of organizational development of educational institutions.

For carrying out an empirical research, the following techniques were used: questionnaire "Are you leader or manager?” (Fraylinger \& Fischer, 2000) and statistical and mathematical methods of data processing with the use of computer SPSS program (version 22).

Two hundred forty-four education managers have selected the examinees - students of master degree program in "Management of Educational Institution" of Kyiv higher educational institutions. The empirical research was carried out in several stages. At the first stage of empirical research, the levels of formation of types of future education managers were determined according to general indicator.

\section{RESULTS}

In order to clarify the level of development of types of education managers' attitude to changes, their readiness to act on the basis of innovative models of management and to introduce the organizational changes corresponding to them, at the second stage of an empirical research, we conducted the interview and the following results were obtained (Table 1). 
Table 1. Level of formation of types of educational institutions managers according to general indicator (in \% of the total number of respondents)

\begin{tabular}{l|c:c:c}
\hline \multirow{2}{*}{ Types of managers } & \multicolumn{3}{c}{ Levels of formation } \\
\cline { 2 - 4 } & High & Average & Low \\
\hline Leader & 34.9 & 35.0 & 30.1 \\
\hdashline Management & 28.1 & 41.6 & 30.3 \\
\hdashline Harmonious & 17.9 & 47.0 & 35.1 \\
\hline
\end{tabular}

High level of leader type is revealed only in $34.9 \%$ of respondents, that is, a third part of respondents. It gives the grounds to claim about the insufficient level of formation of this type of education managers in general.

High level of management type is found only in $28.1 \%$, while $41.6 \%$ have the average level on this component. That is the most part of education managers is guided more by order and stability than by changes. Duty regulations with an accurate formulation of the organizational relations and tasks are important for them. It arises a non-contributing factor for introduction of innovative changes.

The obtained data showed the existence of considerable problems in the development of harmonious management style of education managers. For example, the high level of harmonious style was specified by $17.9 \%$ of respondents; average $-47.0 \%$ and low $-35.1 \%$. It most likely shows the situational behavior of education managers.

According to us, for education managers, the orientation to personal and professional development has to be closely interconnected with orientation to professional life. Education managers need to clearly understand the personal professional purposes and to move in the necessary direction.

The process of introduction of educational changes is structurally and organizationally difficult, demands the resources of various types and high level of individual and organizational readiness for new. Therefore, it is possible to claim that for ensuring effective management of changes (from which the programs of organizational development are formed), education managers have to combine harmonious functions as actually man- agement (administrative) (planning, organization, control), leader (having an indirect impact on workers or order to achieve the organizational objectives of mainly creative, innovative nature).

Let us further analyze the data concerning the second investigation phase aimed at definition of development of types of education managers' attitude to changes. The method allows defining the main types of the personality attitude to changes: "traditionalist", "realist", "freethinker". Defining the education managers' attitude to changes is important when making decision on what kind of change can be introduced in the institution.

Based on the data provided in Table 2, it is possible to draw a conclusion that the interviewed participants of a research concerning changes on the first place (on the level of representation of persons with the high level of expressiveness of a certain type of attitude to changes) are "realist" (46.9\%), further - "traditionalist" (36.7\%), and on the last place, by a significant margin - "freethinker" (12.2\%).

Table 2. The levels of development of types of education managers' attitude to changes (in \% of the total number of respondents)

\begin{tabular}{l|c|c|c}
\hline \multirow{2}{*}{$\begin{array}{c}\text { Types of attitude to } \\
\text { changes }\end{array}$} & $\begin{array}{c}\text { Levels of development of } \\
\text { attitude to changes }\end{array}$ \\
\cline { 2 - 4 } & High & Average & Low \\
\hline Realist & 46.9 & 33.6 & 19.5 \\
\hline Traditionalist & 36.7 & 35.7 & 27.6 \\
\hline Freethinker & 12.2 & 24.5 & 63.3 \\
\hline
\end{tabular}

Obviously, the prevalence of "realist" and "traditionalist" among the interviewed causes insufficient orientation of education managers' to introduction of innovative changes in the educational institutions.

\section{DISCUSSION}

The continuity of development of education in an unstable transitional context is provided through point educational changes. Systemic approach of introduction of gradual and continuous changes is shown in the organizational development of educational institutions. Organizational development has to comply with the following requirements: 
1) to re-inforce those values in which workers feel the need while carrying out the professional duties;

2) to meet the personal needs, inquiries of each employee, relevant to his interests ("context for people");

3) to promote growth of organizational efficiency through effectively and innovatively increasing the internal work motivation of employees, to provide an opportunity for constant professional growth (in particular, through creation of climate of trust, encouragement and cooperation);

4) to create joint environments of training and teaching, integration of science and education;

5) to motivate high-quality activity, to encourage the initiatives and risk taking, to lean on various methods of group work.

Results of the interview showed low orientation of education managers to introduction of innovative changes, in a foreshortening of systematic gradualness and planning on a systematic basis and, according to the strategy of development of the institution, makes process of organizational development. So, future education managers have the low level of readiness to provide organizational development of educational institutions.

Proceeding from procedural features of educational changes, the process of their introduction demands a combination of the developed leader and management functions in so-called "harmonious" type of the education managers. During the research, a low indicator of high level of formation of harmonious type of education managers was recorded.

Formation of education managers readiness for changes is the managed process and can be carried out during the comprehensive training program. Successful leader experience obtained by the education managers in the simulated training situations promotes the formation of their leader image, develops leadership skills and increases motivation. Therefore, introduction of the comprehensive training program in the form of or- ganizational and leader and personal modules is methodologically significant and potentially high productive.

The organizational and leader modules have to be aimed at formation in the simulated situations of communicative and organizational competence, leader, communicative and organizational experience of interaction; formation of skills of self-checking, self-management, persistence. These are the important qualities of the leader, which ensure the success of his organizational and administrative activity, form trust to the leader and readiness to follow him. The personal module is aimed at formation of participants' readiness for innovative changes, increasing the aspiration to personal growth, aspiration to leadership, formation of motivation of success. These individual and personal qualities are necessary for adequate orientation of the manager of education in a situation. The aspiration to leadership and achievements is the factor necessary for self-development and self-improvement of the leader.

Organizational development assumes obligatory interventions of the agent of changes (the education manager the leader) in the process of change of the educational institution (unlike natural development of the institution). These interventions have to be accurately tied to strategic aims and tasks and include methodology and approaches within strategic planning, organizational design, management of results of activity (performance management), coaching, variety and balance between work and private life. It is natural that the embodiment of the concept of organizational development imposes special requirements to not only professional, but also personal qualities of education managers, their leadership skills and administrative culture.

Most of modern Western theorists of organizational development determine the following measurements of educational institution potential, which can be used for ensuring its continuous organizational development:

1) the climate of cooperation with such characteristic features as cooperation, mutual support, collaboration encouragement, constant scientific research, open communication, ex- 
change of information and professional dialogue, honest and direct systematic discussions, etc.;

2) the initiatives and risk taking - creation of conditions under which the employees feel authorized to make decisions (in particular, delegation of powers in the management sphere), constant experiments, the organizational structure of an educational institution that promotes the initiative of teachers, the administration is open to changes, active teachers perceive the value, after all they are rewarded and motivated in a proper way;

3) distribution and monitoring of realization of the institution's mission, shown in creation of curricula according to a mission, constructive dialogue with stakeholders, critical analysis of the available practice of educational and scientific activity, understanding of various forms of impact of the external environment on an institution by the employees;

4) professional development that includes the systems of knowledge management, knowledge exchange, preparation for work and study in a team, resources (including temporary) that ensure the professional development of teachers, studying the best foreign practical experience of professional improvement and involvement of professional consultants (Silins, Mulford, \& Zarins, 2002, p. 618).

Druker describes the ideal education manager as the one who always adheres to uniform administrative style. We agree with the point of view of Adizes (2009) that they do not consider the following fact: different people differently approach the organization, control, motivation. The main management styles, according to Adizes (2009), are a combination of 4 functions, which have to be carried out during the organizational development. If one of these functions is not performed absolutely, it generates dysfunctionality of all control system. If a certain function in administrative activity of the education manager is performed successfully, in a formula of his style, Adizes (2009) suggests to enter the capital letter corresponding to successfully carried out function (P (Producing the results), A (Administering), E (Enterpreneuring) or I (Integrating)), if at the sufficient level, a small letter (p, a, e or i), if it is not shown, minus (-). Ideally, in the conditions of changes, the leading education manager has to be the PaEI-style carrier. As practice shows, it happens seldom, because the best experts are not always good integrators.

In PaEI formula, the management functions broadcast the leader "I" through capital letter "P". Harmonious type of the education manager reflects the effectiveness "E" function and consequently the steady nature of manifestation of this function by the manager of education when the successful planned changes become a basis for continuity of educational changes and make the programs and plans of organizational development viable and effective.

Investigating the leadership problems in education, Sergiovanni, Burlingame, Coombs, and Thurston (1999) note that success of an educational institution is guaranteed if its education manager is capable of presenting and giving others the bright vision of the future of the institution, to turn it, respectively, into accurate organizational tasks, change of structures or activity. Such actions will generate feeling of readiness for changes among those who work in the institution (Sergiovanni, Burlingame, Coombs, \& Thurston, 1999). Therefore, successful education manager focus on educational leadership. According to us, educational leadership also reflects the maintenance of the "harmonious" type of the managers described by us.

According to Coch and French, difficulties on introduction of educational changes arise from organizational imbalances and contradictions, but not from the person (Coch \& French, 1948). Resistance is formed when changes of expectations of the workers and employers contradict each other. At the same time, in view of other theories, it is possible to claim that individual tendencies of the person to accept or reject changes (resistance to changes at the personal level or in Levin's categories - "the strong-willed field") are moderated by an organizational context. It allows to introduce and to operate the changes in order that the change corresponds to a state of organizational environment at some point, but not to assume that certain approach will work under 
any circumstances (Burnes, 2015). When driving forces of changes enter the conflict with forces of resistance, the institutions have to accept the approach to introduce changes that would include a possibility of all interested persons to think about their beliefs and behavior. But this process of "defrosting" (according to Levin) will be effective if interested persons make the decision to change voluntarily. As it was already mentioned, the formed organizational context can significantly influence the emergence of such own will (Semenets-Orlova, 2016, p. 65).

Therefore, the system of master training of education managers needs to be modernized due to addition of training programs with a big range of questions, in particular subjects of the management of strategic priorities of an institution, formation and management of teams, creation of competitive advantages of the educational institution (leader component), achievement of readiness for continuous monitoring of quality of the organizational management, realization through participative management, effective use of material and financial resources for the programs of development, implementation of fundraising, etc. (management component).

During the research, we tried to form the readiness of educational system of Ukraine for introduction of changes, using the obtained indicators of readiness of education managers for organiza- tional development (Figure 1). The last were complemented with indicators of institutional and individual readiness of educators for implementation of the Conceptual New Ukrainian School (as of August 30, 2018, of the readiness by results of expert interviewing, $\mathrm{N}=18$ (institutional readiness $56 \%$ - cell 4 , individual readiness $69 \%$ - cell 2 , Figure 1)) (Semenets-Orlova, 2018). Management and leader indicators were designated in a matrix taking into account the number of the respondents who chose a harmonious style logically:

1) leader: 34.9 (high leader) + 17.9 (high harmonious $)=52.8 \%$ (cell 6 , Figure 1$)$;

2) management: 28.1 (high management) +17.9 (high harmonious) $=46.0 \%$ (cell 8, Figure 1 )

Thus, the obtained matrix reflects the leadership coherence largely with individual readiness of participants for changes. The qualities of the education managers, respectively, correlate from organizational (resource, technological) readiness of educators for introduction of educational changes. In case of $100 \%$ of harmonious style of education managers, in measurement of matrix logic, at the same time, there would have been $100 \%$ indicators of management and leadership skills of the managers (the highest indicator is possible).

In measurement of such matrix approach, the educational industry of Ukraine is ready for intro-

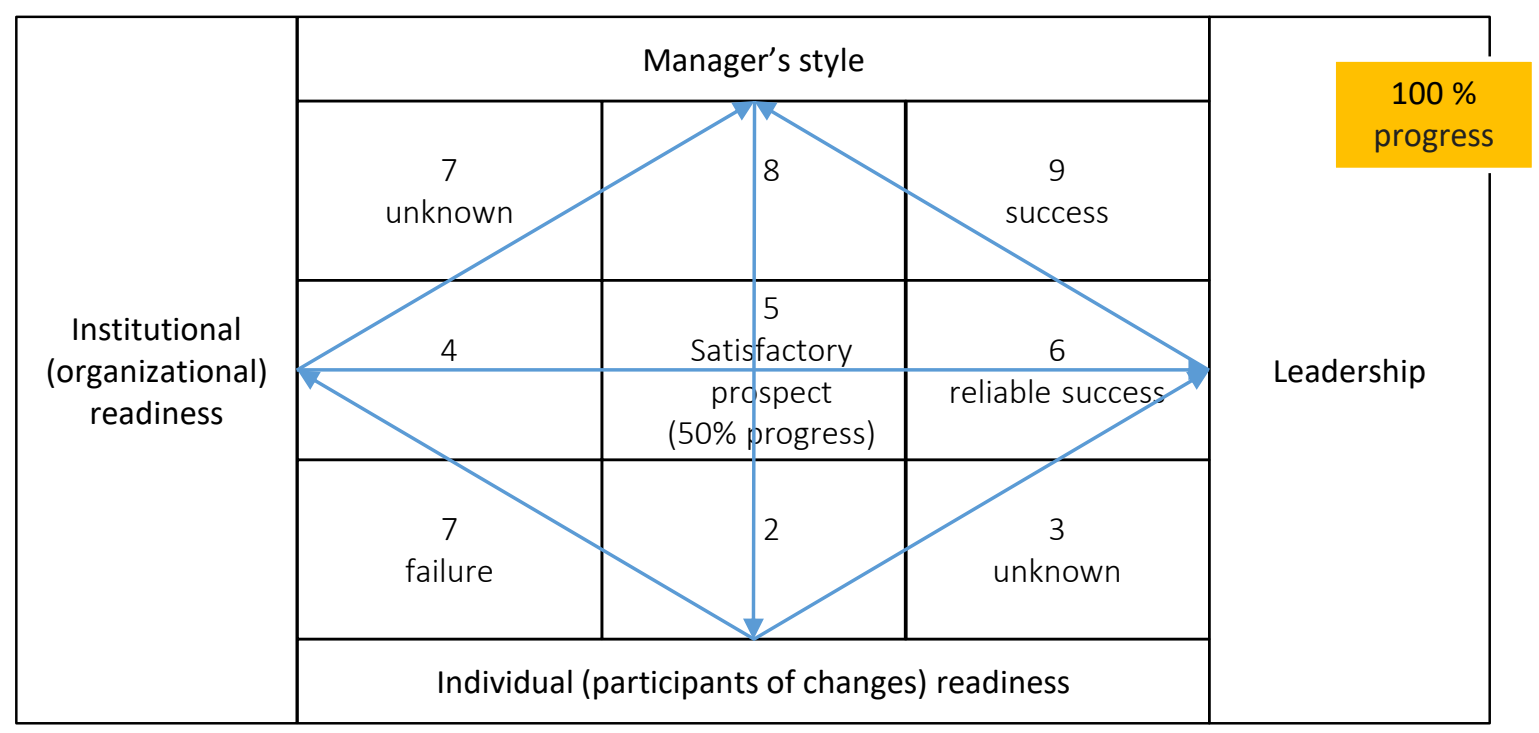

Figure 1. Readiness of educational system of Ukraine for introduction of changes 
duction of changes approximately for $60 \%$. This is a satisfactory indicator. Accordingly, further increase of education managers' readiness to provide the organizational development of educational in- stitutions will naturally create a basis not only for improvement of quality of educational services, but also for successful introduction and strengthening of system educational reform in modern Ukraine.

\section{CONCLUSION}

Education managers in Ukraine show low readiness to introduce educational changes, comprehensive programs of organizational development. Development of harmonious style of management, which is a necessary condition for successful introduction of educational changes at the level of educational institution, is an important component of managers of educational institutions training, which is currently not being implemented effectively.

A set of theories of organizational development determines the educational institution as the dynamic system of elements, which are interconnected; it is the planned, gradual and cyclic process, which begins with the approval of the strategy of development of the institution, proceeds through definition of the operational purposes, planning of experimental projects in joint activity of employees. The traditional theory of leadership of educational institutions demands revision for introduction of the concept of organizational development. In our opinion, it is methodologically significant to consider the "reinvention" and modernization of leader approach through "discovery" of so-called category of harmonious management style by the educational institution. The last provides innovative approaches to development of equally the management (important for resource and organizational support of changes) and the leadership skills of education managers (motivation of personnel to change, overcoming the resistance, motivation to risk, creation of climate of trust and cooperation, the culture of perfection, group work, joint use of results of organizational training). Such approach assumes:

- orientation to problem situations in the course of training;

- application of interactive techniques, case study of role-playing games;

- designing the nonlinear situations of open dialogue with feedback in the course of knowledge transfer;

- formation of educational process as solidary educational adventures through the prevalence of joint activity, practices getting into one self-coordinated pace of education;

- assistance in motivating the education managers to form new forces and abilities and so forth.

The integral condition of realization of such approach is the organizational structure of educational institution, which will allow the employees at all levels to study constantly and share the results of training together.

The results obtained can be used by the government in developing and implementing the programs for the professional development of education managers.

\section{REFERENCES}

1. Adizes, I. (2004). Management/ Mismanagement Styles: how to identify a style and what to do about it. Santa Barbara: The Adizes Institute Publishing.

2. Amanchukwu, R., Stanley, G., \& Ololube, N. (2015). A Review of Leadership Theories, Principles and Styles and Their Relevance to Educational Management. Management, 5(1), 6-14. Retrieved from https://www.researchgate.net/ publication/283081945_A_Review_ of_Leadership_Theories_Principles and Styles_and Their_Relevance to_Educational_Management
3. Blake, R. \& Mounton, J. (1985) The Managerial Grid III: The Key to Leadership Excellence. Houston: Gulf Publishing Co.

4. Burnes, B. (2015). Understanding Resistance to Change - Building on Coch and French. Journal of Change 
Management, 15(2), 92-116. http:// dx.doi.org/10.1080/14697017.2014 .969755

5. Burnes, B., \& Cooke, B. (2012). Kurt Lewin's Field Theory: A Review and Re-evaluation. International Journal of Management Reviews, 15(4), 1-18. https://doi.org/10.1111/j.14682370.2012.00348.x

6. Bush, T., Bell, L., \& Middlewood, D. (2019). Principles of Educational Leadership \& Management. London: SAGE.

7. Cashman, K. (2008). Leadership from the Inside Out: Becoming a Leader for Life. San Francisco: Berret-roehler Publishers.

8. Coch, L., \& French, J. (1948). Overcoming resistance to change. Human Relations, 1(4), 512-532. https://doi. org/10.1177/001872674800100408

9. Cole, M., Hill, D., McLaren, P., \& Ricowski, G. (2001). Red chalk: On schooling capitalism and politics. Bridhton: Institute for Education Policy Studies.

10. Connolly, M., James, C., \& Fertig, M. (2017). The difference between educational management and educational leadership and the importance of educational responsibility. Educational Management Administration \& Leadership, 47(4), 504-519. https://doi. org/10.1177/1741143217745880

11. Druker, P. (2003). Management in the Next Society. New York: Truman Talley Books.

12. Farchi, T., \& Tubin, D. (2018). Middle leaders in successful and less successful schools. School Leadership \& Management, 39(3-4), 372-390. https://doi.org/10.1080/13632434.20 18.1550389

13. Ferraro, G., \& Iovanella, A. (2017) Technology transfer in innovation networks. An empirical study of the Enterprise Europe Network. International Journal of Engineering Business Management, 9, 1-14. https:// doi.org/10.1177/1847979017735748

14. Fraylinger, K., \& Fischer, I. (2000). Managing Change in Organisation. Berlin.

15. Gebert, D., \& Rosenstiel, L. (1981). Organisationspsychologie: Person und Organisation. Kohlhammer: Stuttgart.
16. Goleman, D. (1996). Emotional Intelligence. Why it can matter more than IQ. London: Bloomsbury Publishing.

17. Gummings, T., \& Worley, C. (2009). Organization Development and Change. Mason: South-Western Cengage Learning.

18. Holloway, J., Nielsen, A., \& Saltmarsh, S. (2017). Prescribed distributed leadership in the era of accountability: The experiences of mentor teachers. Educational Management Administration \& Leadership, 46(4), 538-555. https:// doi.org/10.1177/1741143216688469

19. Hura, T. (2018). Leadership Psychology in Business. Psychological Journal, 4(9), 138-151. https://doi. org/10.31108/1.2018.9.19.10

20. Kotter, J. (2012). Leading change. Harvard: Harvard Business Review Press.

21. Kotter, J., \& Cohen, S. (2012). The Heart of Change. Harvard: Harvard Business Review Press.

22. Kuczmarski, S. (2007). Apples and Square. Thinking differently about leadership. New York: Kaplan Publishing.

23. Leavitt, H., \& Lipman-Blumen, J. (2001). Groups: Seeding Them, Feeding Them, and Using Them to Ignite Your Organization. Oxford: Oxford University Press.

24. Omelyanenko, V., Semenets-Orlova, I., Khomeriki, O., Lyasota, L., \& Medviedieva, Yu. (2018). Technology transfer management culture (education-based approach). Problems and Perspectives in Management, 16(3), 454-463. https://doi. org/10.21511/ppm.16(3).2018.36

25. Ronen, I. (2019). Education leadership in the knowledge age "from a formal position to a formative perception" the case of learning communities. Professional Development in Education, 45(1), 73-86. https://doi.org/10.1080/19415257.20 18.1514526

26. Salmi, J. (2009). The Challenge of Establishing World-Class Universities. Washington, DC: The World Bank.

27. Semenets-Orlova, I. (2017). Processual aspects of educational changes: empirical findings at institutional level. Advanced Education, 1(7), 6467. https://doi.org/10.20535/24108286.82887

28. Semenets-Orlova, I. (2018). Tendencies in reforming the educational system of modern Ukraine: national and regional aspects. Public management: collection, 2(12), 171-179. https://doi.org/10.31618/vadnd. vli12.91

29. Senge, P. (2006). Fifth Discipline: The Art and Practice of the Learning Organization. Doubleday: Random House.

30. Sergiovanni, T., Burlingame, M., Coombs, F., \& Thurston, P. (1999). Education governance and administration. Boston, MA: Allyn \& Bacon.

31. Shahrill, M. (2014). Exploring Educational Administration: The Relationship between Leadership and Management. International Journal of Academic Research in Business and Social Sciences, 4(1), 525-538. https://doi.org/10.6007/ IJARBSS/v4-i1/557

32. Silins, H. C., Mulford, W. R., \& Zarins, S. (2002). Organizational Learning and School Change. Educational Administration Quarterly, 38(5), 613-642. https://doi. org/10.1177/0013161X02239641

33. Stalnaker, D. (2018, October 23). Industrial and Organizational Psy chology: Humans and Organizations. http://doi.org/10.2139/ssrn.3271653

34. Tichy, N., \& Cohen, E. (2002). The leadership engine: How winning companies build leader at every level. New York: Harper Business. 